\title{
Preparing Tomorrow's Engineer-Communicators: A Review of Models for Effective Communication Instruction
}

Meghan Marshall ${ }^{1}$, Lydia Wilkinson ${ }^{2}$, Viviane Yargeau ${ }^{1}$, Maria Orjuela-Laverde ${ }^{1}$, Myra Bloom ${ }^{3}$, Brandiff Caron ${ }^{3}$, Louise Meunier ${ }^{4}$, Greg Zilberbrant ${ }^{5}$; Paul Okrutny ${ }^{5}$; Jonathan Verrett ${ }^{6}$; Michael Schoen $^{6}$; Estella Qi ${ }^{6}$;Tatiana Teslenko ${ }^{6}$; Kelly Miller ${ }^{7}$; Hassan Golpour ${ }^{8}$

\author{
1: McGill University; 2: University of Toronto; 3: Concordia University; Queen's University; 5: \\ McMaster University; 6: University of British Columbia; 7: Harvard; 8: North Carolina State \\ University
}

meghan.marshall2@mail.mcgill.ca, 1ydia.wilkinson@utoronto.ca

\begin{abstract}
This paper offers a landscape analysis of communication instruction within six Canadian and two American Engineering faculties by bringing together approaches and perspectives from communication instructors at these institutes. Each instructor shares a summary of their institution's approach to communication instruction, before discussing a course-level initiative. Similarities between these approaches at a course and institutional level are summarized and discussed.
\end{abstract}

Keywords: Engineering communication, technical communication, communication skills, communication instruction, instructional models, curriculum development

\section{INTRODUCTION}

The importance of fostering effective communication skills in future engineers is largely undisputed today. Their instruction has been formalized by both the CEAB and ABET requirements $[1,2]$, while workplace studies provide evidence for their importance in a student's career success [3-11]. Consensus on the value of these skills may explain the sparsity of materials on comparative instructional models: embedded engineering communication programs and faculty have emerged in the last thirty years as a response to earlier discussions on the need for this instruction [12-16], but a revived conversation about what is happening between institutions has yet to gain traction. A 2004 survey of communication instruction in 73 topranked North American engineering schools provides the most comprehensive study of this field to date, and for its high-level categorizations this survey is quite valuable; though the relevance of its findings is undermined by the rapidly evolving nature of this field [17]. Writing Across the Curriculum (WAC) and Writing in the Discipline (WID) conferences and publications provide one forum in which communication instructors can share their approaches to WAC in Science Technology Engineering and Mathematics (STEM), but these conversations may fail to capture activities in institutions where communication, and transdisciplinary skills instruction, is closely integrated into the core curriculum. Communication societies within larger engineering associations (IEEE's ProComm or ASEE's LEES for example) provide other spaces to share approaches to communication instruction, but perspectives are often limited to the activities of one institution or instructor. The most comprehensive survey to date of communication instruction is over a decade old, and its accuracy may be marred by the tendency of communication models and mechanisms to change with the administrative structures that guide curricular development. An up-to-date comparison of existing models, pedagogical approaches and corresponding organizational structures can provide an important resource for communication instructors within engineering education and engineer educators interested in integrating and supporting this instruction.

This paper offers a landscape analysis of how communication is delivered within six Canadian and two American Engineering faculties by bringing together approaches and perspectives from 15 communication instructors. The idea for this paper was conceived while redesigning an engineering communication course at McGill University, which involved an investigation into current best practices for communication skills training at other institutions. McGill identified instructors teaching engineering communication courses through personal networks, colleague referrals and internet searches (a particular focus was placed on communication in Chemical Engineering based on the faculty need). These instructors were invited to participate in interviews, in which information was collected such as the primary course objective(s), course structure/ approach, major assessments, homework and course name, department, 
size, level and any other information the instructor though was important to their course.

This information gathering process provided a partial landscape of approaches being used at different institutions, which will be of interest to engineering communication instructors and engineering educators incorporating communication instruction into their engineering courses. Here, each instructor shares a summary of their institution's approach to communication instruction, before discussing a course-level initiative.

\section{INSTITUTIONAL REVIEW}

The information gathering process provided a partial landscape of approaches being used at different institutions, which will be of interest to engineering communication instructors and engineering educators incorporating communication instruction into their engineering courses. Here, each instructor shares a summary of their institution's approach to communication instruction, before discussing a course-level initiative.

\subsection{McGill University}

At McGill University, within the Faculty of Engineering, all engineering students develop their communication skills through several courses including mandatory faculty courses (FACC course code) that are designed to target professional skills, including those of oral and written communication. All disciplines, with the exception of Chemical Engineering, are required to take a course given by the McGill Writing Centre called Communication in Engineering (COMM 206), which targets written communication skills. Chemical Engineering requires students take a course given by a departmental faculty member, called Technical Report (CHEE 360), which focuses on written technical communication. The program in Chemical Engineering is currently being revised to integrate elements of communication in the fourth-year capstone design courses Design Project I \& II (CHEE 456/457).

Over the two-semester sequence, Design Project I \& II, students work in teams on an industrial project under the supervision of a professional engineer as their leader and a faculty member. The integration of activities to support the development of communication skills in the capstone design course aims at simulating more closely real-life professional engineering experiences, to increase the level of peer and instructor feedback and formative assessment. The new communication objectives are to: (1) train and assess communication skills in a context of technical work, and (2) guide the development of technical report writing and oral presentation skills to attain a level of proficiency at which students will excel when they enter the workplace. The new components and activities designed for the course have been inspired by the communication courses offered by the other authors in this paper and a literature review. In the first semester, in Design I, four workshops have been designed to progressively advance the writing of deliverables required for the design project. Students are expected to complete pre-workshop homework including readings and a written assignment that they will edit during the workshop using peer assessment strategy and feedback from the instructor. For each written assignment, both good and bad examples of previous student work are provided. In our experience, students at this level typically have not been exposed to high-quality, high-impact editing, therefore, the objective of the first workshop is to train students to edit self and peer works. In the second and third workshop, students edit sections of a technical report with a focus on improving structure, flow, style, and inclusion of appropriate content. In preparation for the fourth workshop, students will be required to film themselves giving a 3-minute presentation on their design project. During the workshop, students and the instructor will discuss and formatively assess the recorded presentations. Major summative assessments over the two semesters validating the application of the skills developed include a technical report and a presentation to the design leaders, instructor and their peers at the end of each semester.

\subsection{University of Toronto}

At University of Toronto, communication instruction is provided through the Engineering Communication Program (ECP), a unit within the Institute for Studies in Transdisciplinary Engineering Education and Practice (ISTEP). Communication is coordinated within each of the Faculty's eight engineering departments (Chemical, Civil, Electrical and Computer, Engineering Science, Mechanical and Industrial, Material Science) and first year, by one of the unit's seven full-time faculty, which also includes a professional language specialist. Instruction is supported by a team of approximately twenty sessional instructors who are closely connected with the department, as well as a team of teaching assistants.

This centralized model supports collaboration and consensus building between University of Toronto core faculty, who have devised and implemented key communication principles (based on the CEAB criteria) which have been mapped across all four years. At the same time, our connections with affiliate departments allow each faculty member to devise instruction while working with engineering faculty, that responds to disciplinary needs and norms. Across departments and years communication instruction varies but will generally be delivered in one of three ways: 1) in standalone communication courses; 2 ) in co-instructed and devised communication and design courses; or 3) in communication-focused projects that are supported by our faculty but delivered in core technical courses. These communication offerings are generally required, but the recent addition of a Certificate in 
Communication recognizes students who have chosen to take additional communication-focused courses from our suite of in-house electives.

Communication (CHE 299) is one example of a standalone communication course in Chemical Engineering. Over the last year this course has undergone considerable change, which is reflective of the evolving nature of communication instruction and the importance of responding to institutional and departmental need. Since its creation in 2013, CHE299 has focused on the following learning objectives:

- Become familiar with different types (genres) of communication and their conventions;

- Analyze audience and purpose to select most effective mode/genre of communication, and level of detail required;

- Develop clear and persuasive messages through effective argumentation;

- Find and properly integrate relevant information to support purpose and argument;

- Summarize and synthesize information from external sources;

- Effectively organize information and prioritize it in each mode of communication (written, visual, oral) to convey message;

- Apply effective strategies to the design of text, visuals and oral presentations;

- Develop self-confidence as a communicator.

Instruction in the course is delivered via two weekly activity-based tutorials of approximately 25-30 students, led by a single tutorial instructor, but planned by the communication coordinator in consultation with a teaching partner in Chemical Engineering. Most deliverables are closely linked to activities in the core curriculum, and most recently have focused on written components of a project lab in the laboratory chemistry course. In the past, a summative group presentation in which students recommend a curriculum change has synthesized learning and reinforced the course's close connection with other classes.

This year, the course is undergoing considerable change. While first semester remained closely linked to the laboratory course, the second semester no longer focuses on the additional group assignment. Instead, the course has been restructured around an existing consulting project, which was previously housed in an environmental chemistry course. The delivery of the project has not changed significantly, but the new framework repurposes course tutorials as workshops focused not only on communication but a range of related transdisciplinary skills, including professionalism, ethics, and project management. This new model highlights the type of innovative instruction that is made possible through collegial collaboration that sees communication as an integral component of the engineering curriculum.

\subsection{Queen's University}

At Queen's University, communications courses are part of the mandatory engineering practice curriculum. In first and second years, introduction to technical writing and professional skills classes are delivered through facultylevel courses (APSC codes). Upper year courses are taught within each department, where communication is either offered in dedicated courses (CHEE, CIVL, MECH, MINE, MNTC), or integrated with design, research skills, and professional practice courses (CMPE, ELEC, ENPH, GEOE, MTHE). These courses introduce, develop, and apply learning objectives based on CEAB criteria. At all levels, communication courses are coordinated by engineering faculty and supported by lecturers and teaching assistants with specialized skills in technical writing. Furthermore, the Engineering Teaching and Learning Lab provides support for course development (e.g. written materials, instructional videos, case studies, etc.). Students also have access to complementary instruction by professional language specialists in the Faculty of Engineering and Applied Science, and may seek additional help from Student Academic Success Services.

In Chemical Engineering, communication abilities are developed in a professional skills course offered to third-year students. CHEE 361 Engineering Communications, Ethics, and Professionalism is a onecredit course and co-requisite with CHEE 331 Design of Unit Operations. The previous version of CHEE 361 focused exclusively on technical communication. In 2018, ethics and professionalism were incorporated into the new course to place special emphasis on these important aspects of professional development. The learning objectives are:

- To critically evaluate written material, including scholarly sources;

- To present concise, coherent, and grammatically correct materials (written and oral) that reflect critical analysis and synthesis, and appropriately address the needs of the audience;

- To create accurate and complete technical graphics to explain, interpret, and assess information;

- To deliver formal and informal oral presentations with appropriate language, style, timing, and flow;

- To apply principles of engineering ethics and equity to issues encountered in engineering practice; and

- To analyse social and environmental aspects of engineering activities. 
Students are divided into two workshop sections of approximately 45 students each. The course is presented in six modules: (1) Technical Communication, (2) Citation, (3) Oral Presentation, (4) Job Search Skills, (5) Ethics, Equity, and Social Responsibility, and (6) Technical Report. Once per week, a two-hour interactive workshop includes short exercises on grammar and syntax specifically targeting technical writing, followed by presentations on a specific module. Workshops are led by the instructor and supported by a professional engineer and a teaching assistant. The second hour of workshops is reserved for students to focus on their own assignments. Tasks include preparing documents and oral presentations, and editing another student's work. Students are assessed on annotated bibliographies, technical memos, oral presentations, a cover letter and curriculum vitae in response to a real job posting, reflections following ethics and equity case studies, and CHEE 331 reports. The course goal is to prepare students for the oral and written components of their capstone design courses and for junior engineering positions.

\subsection{Concordia University}

The Gina Cody School of Engineering and Computer Science at Concordia University relies on the Centre for Engineering and Society to deliver communication skills to all ENC students. The Centre for Engineering and Society is a unique model for addressing societal and ethical implication of engineering practice in engineering education in Canada. We are social scientists (philosophers, rhetoricians, anthropologists, sociologists, and humanists) who study and teach about the social, ethical, and legal implications of engineering practice. Part of the mission of the Centre is to help students acquire and refine the ability to communicate.

All students admitted into the Gina Cody School of Engineering and Computer Science must satisfy the School's writing skills requirement prior to being eligible to enroll in the mandatory "Technical Communication" course that serves as a prerequisite for higher level engineering courses across the faculty. This requirement can be satisfied in one of two ways. Students may take the Engineering Writing Test (EWT). If the student passes this test, they are then eligible to enroll in the Technical Communication course. If the student fails to pass the EWT twice, the student must enroll in our "Argumentation and Composition for Engineers" course and receive better than a C- in this course in order to satisfy the writing requirement and become eligible to enroll in the mandatory Technical Communication course.

Technical Communication (ENCS 282) is a mandatory lecture-tutorial-style course for all ENC second-year students in which they are exposed to the professional norms of oral and written technical communication within engineering. This course aims to promote the ability to think and express ideas critically, clearly and analytically. Course learning objectives include:

- Identify audience needs, interests and level of knowledge

- Frame supportable, significant these and arguments

- Develop appropriate expository and argumentative strategies

- Identify and utilize relevant, high quality resources

- Create drafts and revisions

- Respond to critical feedback

- Demonstrate understanding of cognitive and conceptual differences between oral and written presentation

- Create appropriate scope for treatment of topic in oral presentation

- Adapt written text to oral presentation

- Identify audience needs, interests and level of knowledge

- Plan, design and effectively utilize visual materials

- Utilize effective presentation techniques

- Identify strategies to overcome linguistic difference

- Adapt presentation to heterogeneous audiences

Readings are assigned to students to read before each lecture, in which their active participation is assessed. The tutorial is run as a workshop where students produce a variety of written works, which also count towards their participation grade. Students are assessed on oral and written communication assignments prepared out of class including: a mechanism description, a feasibility report, rhetorical analysis, a major research proposal (modelled on an actual NSERC proposal) and a presentation on their proposal.

\subsection{McMaster University}

McMaster University's Faculty of Engineering delivers communication at the departmental level either though courses directly aimed at addressing communication skills or as a component within a technical course. McMaster also offers unique programs that focus on the development of professional skills and general management skills throughout the undergraduate level. Two of these offerings are, Engineering and Society, a five-year program that combines traditional engineering programs with additional courses all of which have a strong focus on oral and written communication, and Engineering and Management, a fourand-a-half-year program with management courses reinforcing communication skills in an experiential 
learning environment. These offerings are unique in the way that communication is taught. Engineering and Society courses have a strong focus on group work, presentations, and in-class debate while Engineering and Management courses integrate communication in a format that would be expected in a business environment through small group meetings with instructional staff, meeting minutes, and presentations in a boardroom environment. The goal in both programs is to have students communicate more effectively in various professional settings.

Technology and society (3Y03) is an example of a typical course taught in Engineering and Society. This third-year interactive workshop-style course runs yearly with approximately 40 students. The theme of this course is to investigate the interplay between society and technology, and what this interplay means for both engineers and broader society. The aim of this course is to allow students to practice the inquiry process whereby they seek understanding of a complicated issue through a process of asking relevant questions and seeking answers through relevant research. The three hour, weekly, classroom sessions at the start of the semester are instructor-facilitated discussion where students identify points of agreement, contention, and divergence amongst their peers over certain aspects of the culture-technology relationship. These discussions help set the theme of the course and the high level of class participation and communications expected. Midway through the course, the sessions transition into student-led seminars discussing topics that the students have researched during their inquiry study. Students are assessed on: their participation throughout the semester; their seminar presentation and facilitation; a written reflection at the beginning and end of the semester; and four assignments, each of which build on each other. Students are encouraged to facilitate their seminars in unique ways, staying away from the typical slide presentations and instead utilizing field trips, games, storytelling and physical interaction to communicate findings.

\subsection{University of British Columbia}

At the University of British Columbia's Faculty of Applied Science, a second-year communication course is stipulated in the Standard Time Table for all engineering students, but communication content is integrated differently in each engineering program. Communication instructors in applied science are both departmental communication faculty/lecturers and faculty-level lecturers. Three common models for communication integration have emerged at UBC: project-based full integration, course-based partial integration and topicbased thematic integration. All engineering departments also have one or two courses in $2^{\text {nd }}$ and $3^{\text {rd }}$ year related to professional practice which bring in guest speakers from industry. In mining and civil engineering, the communication instructors are involved in the teaching of those courses. In fourth year, all engineering students are required to complete a capstone design course, which is team taught by engineering professors; input is provided by communication instructors in civil and mining engineering.

Mechanical Engineering 226 is one example of a project-based communication course for students in Mechanical Engineering. It is integrated with several mechanical engineering courses in the Mech 2 curriculum. As a co-requisite for the Mech 2 program, it runs for two terms and is mandatory for all students in the program. Students prepare design reports, as well as verbal, online and visual presentations of technical material related to their projects. Term 1 has one major report, completed outof-class; Term 2 is scheduled around two competitions devoted to Mech 2 projects. Each competition is preceded by an open-house event that showcases students' prototypes and posters. After each competition student teams deliver oral presentations and submit formal recommendation reports. The course has two exams: a midterm and a final exam.

\subsection{Harvard University}

Harvard University's John A. Paulson School of Engineering and Applied Sciences (SEAS) addresses communication at the faculty level through a professional writing course and as a component of technical courses. The writing course is not required and is open to any undergraduate student, regardless of concentration. It is taught by a SEAS faculty member and the director of the Harvard University writing center. The technical courses that include communication as a substantial part of the curriculum are designed for students concentrating in engineering and other STEM disciplines. Despite this, these courses are not closed to undergraduates concentrating in other disciplines. These technical courses are taught by SEAS faculty members (both tenured professors and lecturers). While the focus of these courses is discipline-specific content, the skill of communication is emphasized throughout. Much of the assessment of these courses is based on clear and effective written and oral communication. One such technical course in which communication has been majorly integrated is outlined.

Applied Physics 50 (AP50) is a project-based, introductory physics course offered through the school of engineering. AP50 satisfies the requirement for any concentration that requires introductory physics, although the course was designed specifically with engineering students in mind. While the enrollment is open to any undergraduate student, the course is capped at 75 students and, due to demand, an enrollment lottery is necessary most semesters. Preference is given, in the lottery, to engineering students. The goal of this course is to master 
fundamental concepts in physics through self-directed learning, teamwork and projects.

As there are no lectures in AP50, students are expected to read the textbook online and develop a certain level of comfort with the material before coming to class. Then, while in class, students work in small teams on projects and activities that are designed to help them better learn the material. The pedagogy used in AP50 draws on features of project-based and team-based learning. All of the learning goals for AP50 are addressed through three projects that students work on in class, with three different teams. Students work within these groups for all aspects of the course, including assessments, which are taken together as a team. At least part of the success of team-based learning is attributable to the fact that students work harder because they are made to feel accountable to their teammates, and in this course, students evaluate their teammates' contributions and this assessment contributes significantly to the final grade.

AP50 meets twice weekly for 3 hours, in which students engage in six different types of in-class activities which include: pre-class reading assignments and annotation on Perusall, Learning Catalytics questions, an estimation activity, a readiness assurance activity, and experimental design activity and problem-set reflection (problem-sets have been completed pre-class). In addition to having time to work on the projects, students use time in class engage in one to three of these activities, which are scheduled into each of the blocks of class time. Each of these class activities are designed to help students master the relevant physics and get started on the projects, which serve as the focal point for the course.

At the end of each project, students are assessed on the production of a final report which should be suitable for submission to a scientific journal and the presentation of their project to a panel of judges that are brought in from outside the department. Over the course of AP50, students write final reports and do oral presentations three times (for each of the three projects). Each time they are assessed with rubrics designed to provide feedback on both written and oral communication skills.

\subsection{North Carolina State University}

The College of Engineering at North Carolina State University delivers instruction in communication skills at the departmental level. In chemical engineering, communication is delivered as a component within technical courses such as lab courses and design projects, and through a professional development seminar specifically targeted to instruct communication skills. An overview of an engineering lab course is described below.

Chemical Engineering Lab I: Unit Operations (CHE 330) is a third-year course consisting of lecture and laboratory sections; typically there are approximately 35 students enrolled in the fall and 100 enrolled in the spring.
Although this is a technical course, a large part of the course learning objectives are focused on training communication; they are as follows:

- Produce written technical reports as part of an engineering team.

- Orally present technical information as part of an engineering team.

- Capably perform hands-on engineering as part of an engineering team.

- Solve problems using statistics relevant to engineering.

- Design and analyze an experiment using factorial experimental design principles.

- Identify causes and preventative measures for process safety incidents.

Lectures are 50 minutes each and cover both technical and communication-related topics, including statistics, lab safety, report writing, and oral presentations. Four lectures in CHE 330 are assigned to technical writing cover topics such as formatting, report outline, plagiarism and citation. Three lectures address how to make effective PowerPoint slides and a poster, as well as tips and tactics on how to present professionally, while the remaining two lectures address safety and ethics in chemical engineering. In the lab section, students are assigned to groups of four and are required to perform four labs in their teams. For each lab, groups write a full technical report and present a professional presentation (both PowerPoint and Poster) to the instructor and their fellow classmates.

\section{COMPARISON OF PROGRAM MODELS}

The panelists' positions as practicing educators gives them valuable insight into the way that engineering communication is taught in practice, specifically within the courses in which they are involved. A website review of required and elective courses provides a more complete picture of the administrative structures and program-level curriculum in which these courses are situated. Table 1 summarizes website information on program-level requirements and the departments that fulfill these program-level requirements. The second column (Administrative Structure) identifies where communication is delivered: through a centralized department, like the Engineering Communication Program or the Centre for Engineering and Society; in a service course, taught by another department such as English; at the Faculty level, through required courses taught by Engineering faculty or sessional lecturers; or at the department-level, through courses developed and instructed within a given department by one of its Faculty. The other columns clarify information about the specific courses referred to under Administrative Structure. This 
table highlights communication courses expressly, and does not attempt to capture communication instruction as assignment design within otherwise technical courses.

Table 1. Comparison of Administrative Models

\begin{tabular}{|c|c|c|c|c|}
\hline Institution & Administrative structure & $\begin{array}{l}\text { Faculty-wide } \\
\text { requirements }\end{array}$ & $\begin{array}{l}\text { Department-level } \\
\text { instruction }\end{array}$ & $\begin{array}{l}\text { Electives, minors and } \\
\text { certificates }\end{array}$ \\
\hline $\begin{array}{l}\text { University of } \\
\text { Toronto, Faculty } \\
\text { of Applied } \\
\text { Science and } \\
\text { Engineering }\end{array}$ & $\begin{array}{l}\text { Centralized unit: The } \\
\text { Engineering Communication } \\
\text { Program (ECP), in the Institute } \\
\text { for Studies in Transdisciplinary } \\
\text { Engineering Education and } \\
\text { Practice oversees } \\
\text { communication across the } \\
\text { Faculty via a coordinator } \\
\text { assigned to each department, as } \\
\text { well as running a writing } \\
\text { centre. }\end{array}$ & $\begin{array}{l}\text { A two semester } \\
\text { Design and } \\
\text { Communication } \\
\text { course sequence } \\
\text { for all first-year } \\
\text { students. }\end{array}$ & 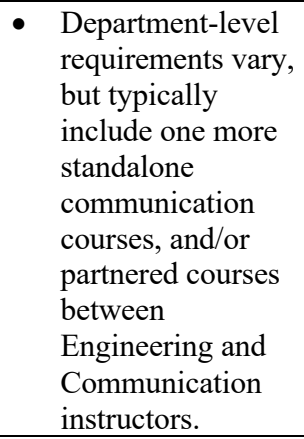 & $\begin{array}{l}\text { ECP electives } \\
\text { leading to a } \\
\text { Certificate in } \\
\text { Communication }\end{array}$ \\
\hline $\begin{array}{l}\text { McGill } \\
\text { University, } \\
\text { Faculty of } \\
\text { Engineering }\end{array}$ & $\begin{array}{l}\text { Service course/faculty- } \\
\text { level/department-level: } \\
\text { Communication instruction is } \\
\text { delivered via department- } \\
\text { specific courses and a course in } \\
\text { the McGill Writing Centre. } \\
\text { Faculty-level courses (course } \\
\text { code: FACC), cover } \\
\text { communication alongside other } \\
\text { complementary skills. }\end{array}$ & $\begin{array}{l}\text { COMM 206: } \\
\text { Communication in } \\
\text { Engineering, } \\
\text { offered by the } \\
\text { McGill Writing } \\
\text { Centre } \\
\text { - Faculty courses on } \\
\text { professional skills } \\
\text { include a } \\
\text { communication } \\
\text { component } \\
\text { (FACC 100, } \\
\text { FACC 220, FACC } \\
300 \text { and FACC } \\
400)\end{array}$ & $\begin{array}{l}\text { Additional } \\
\text { engineering } \\
\text { communication } \\
\text { courses required } \\
\text { in some } \\
\text { departments (e.g. } \\
\text { CIVE 432) }\end{array}$ & \\
\hline $\begin{array}{l}\text { Queen's } \\
\text { University, } \\
\text { Faculty of } \\
\text { Engineering and } \\
\text { Applied Science }\end{array}$ & $\begin{array}{l}\text { Faculty-level/department-level: } \\
\text { Communication instruction is } \\
\text { delivered via a faculty-level } \\
\text { course (course code: APSC), } \\
\text { with some departments } \\
\text { requiring additional } \\
\text { communication courses. }\end{array}$ & $\begin{array}{l}\text { - APSC293: } \\
\text { Engineering } \\
\text { Communications }\end{array}$ & $\begin{array}{l}\text { Additional } \\
\text { engineering } \\
\text { communication } \\
\text { courses required } \\
\text { in some } \\
\text { departments (e.g. } \\
\text { CHEE361) }\end{array}$ & \\
\hline $\begin{array}{l}\text { Concordia } \\
\text { University, Gina } \\
\text { Cody School of } \\
\text { Engineering and } \\
\text { Computer } \\
\text { Science }\end{array}$ & $\begin{array}{l}\text { Centralized unit: } \\
\text { Communication courses are } \\
\text { delivered by the Centre for } \\
\text { Engineering and Society } \\
\text { (course code: ENCS). In } \\
\text { addition to communication } \\
\text { courses the Centre runs } \\
\text { required courses on the impact } \\
\text { of technology on society } \\
\text { (course code: ENGR) that } \\
\text { include significant } \\
\text { communication components. }\end{array}$ & $\begin{array}{ll}\text { ENCS } 272 \\
\text { Composition and } \\
\text { Argumentation for } \\
\text { Engineers } \\
\text { - ENCS 282: } \\
\text { Technical Writing } \\
\text { and } \\
\text { Communication } \\
\text { - Related courses } \\
\text { including ENGR } \\
\text { 392: Impact of } \\
\text { Technology on } \\
\text { Society } \\
\end{array}$ & & $\begin{array}{l}\text { Electives offered } \\
\text { through Centre for } \\
\text { Engineering in } \\
\text { Society }\end{array}$ \\
\hline $\begin{array}{l}\text { McMaster } \\
\text { University, }\end{array}$ & $\begin{array}{l}\text { Faculty-level/department-level: } \\
\text { Communication courses are }\end{array}$ & $\begin{array}{l}\text { - A course in the } \\
\text { core first year }\end{array}$ & & $\begin{array}{l}\text { - 5-year programs in } \\
\text { Engineering and }\end{array}$ \\
\hline
\end{tabular}




\begin{tabular}{|c|c|c|c|c|}
\hline $\begin{array}{l}\text { Faculty of } \\
\text { Engineering }\end{array}$ & $\begin{array}{l}\text { developed and delivered by } \\
\text { each department in second or } \\
\text { third year. In the common first } \\
\text { year, a required faculty-level } \\
\text { course covers communication } \\
\text { alongside other professional } \\
\text { skills. }\end{array}$ & $\begin{array}{l}\text { (ENG 1P03: } \\
\text { Engineering } \\
\text { Profession and } \\
\text { Practice) covers } \\
\text { communication } \\
\text { alongside ethics, } \\
\text { health and safety, } \\
\text { roles and } \\
\text { responsibilities to } \\
\text { society, } \\
\text { sustainability, } \\
\text { design skills and } \\
\text { team design } \\
\text { projects. }\end{array}$ & & $\begin{array}{l}\text { Management and } \\
\text { Engineering and } \\
\text { Society incorporate } \\
\text { more communication- } \\
\text { focused activities. }\end{array}$ \\
\hline $\begin{array}{l}\text { University of } \\
\text { British Columbia } \\
\text { Faculty of } \\
\text { Applied Science }\end{array}$ & $\begin{array}{l}\text { Service course/faculty- } \\
\text { level/department-level: After a } \\
\text { common first year, a required } \\
\text { communication course is } \\
\text { offered by department or at the } \\
\text { faculty-level. }\end{array}$ & $\begin{array}{l}\text { ENGL 112: } \\
\text { Strategies for } \\
\text { University Writing } \\
\text { delivered by } \\
\text { Student Service } \\
\text { Centre } \\
\text { - APSC201: } \\
\text { Technical } \\
\text { Communication } \\
\text { (or a department- } \\
\text { specific } \\
\text { alternative) }\end{array}$ & $\begin{array}{l}\text { - Additional } \\
\text { engineering } \\
\text { communication } \\
\text { courses required in } \\
\text { some departments } \\
\text { (e.g. MECH 227) }\end{array}$ & \\
\hline $\begin{array}{l}\text { Harvard } \\
\text { University, John } \\
\text { A. Paulson } \\
\text { School of } \\
\text { Engineering and } \\
\text { Applied Sciences } \\
\text { (SEAS) }\end{array}$ & $\begin{array}{l}\text { Service course/college-level: } \\
\text { The general education (GE) } \\
\text { degree exposes students to } \\
\text { complementary studies from } \\
\text { other departments concurrently } \\
\text { with their Engineering major. } \\
\text { First year students are required } \\
\text { to complete an expository } \\
\text { writing course through the } \\
\text { Harvard College Writing } \\
\text { Program. }\end{array}$ & $\begin{array}{l}\text { Expos 20: } \\
\text { expository writing } \\
\text { course (first year } \\
\text { requirement for all } \\
\text { Harvard College } \\
\text { students) }\end{array}$ & $\begin{array}{l}\text { - ES 96/227: } \\
\text { Engineering Problem } \\
\text { Solving \& Design } \\
\text { Project } \\
\text { - ES 100: Engineering } \\
\text { Design Projects } \\
\text { - Both these courses } \\
\text { emphasize written } \\
\text { and verbal } \\
\text { communication } \\
\text { skills and are } \\
\text { mandatory for } \\
\text { engineering students } \\
\text { in their } 3^{\text {rd }} \text { and } 4^{\text {th }} \\
\text { years }\end{array}$ & $\begin{array}{l}\text { Expos 40: elective } \\
\text { offered through } \\
\text { Harvard College } \\
\text { Writing Program, } \\
\text { focus is to help } \\
\text { students discover and } \\
\text { hone their "voice" as } \\
\text { a speaker }\end{array}$ \\
\hline $\begin{array}{l}\text { North Carolina } \\
\text { State University, } \\
\text { College of } \\
\text { Engineering }\end{array}$ & $\begin{array}{l}\text { Service-course/department- } \\
\text { level: A first year academic } \\
\text { writing course is required by } \\
\text { all departments, with most also } \\
\text { requiring a third-year } \\
\text { engineering communication } \\
\text { course, both run by the English } \\
\text { Department, or by the } \\
\text { Communication Department. } \\
\text { Some departments require } \\
\text { additional in-house courses. }\end{array}$ & $\begin{array}{l}\text { ENG 101: } \\
\text { Academic Writing } \\
\text { and Research } \\
\text { delivered by the } \\
\text { English } \\
\text { Department } \\
\text { - ENG331: } \\
\text { Communication } \\
\text { for Engineering } \\
\text { Technology (or } \\
\text { limited } \\
\text { alternatives from } \\
\text { English or } \\
\text { Communication } \\
\text { departments) }\end{array}$ & $\begin{array}{l}\text { - Additional } \\
\text { engineering } \\
\text { communication } \\
\text { courses required and } \\
\text { run by some } \\
\text { departments (e.g. } \\
\text { CHE 395) }\end{array}$ & \\
\hline
\end{tabular}




\section{DISCUSSION}

Both similarities and differences emerge in this limited sample of programs, both at a classroom and administrative level. First, seven of the eight instructors report that communication instruction is delivered at the department level, either through all four years or beyond the second or third. All but two instructors report that these departmental initiatives are underpinned by a faculty-level required communication course in the first or second year, with the website survey filling out this data to confirm that all programs require some type of foundational writing or communication course. The website search indicates that half of these courses are service courses and half are offered by the engineering faculty.

Two of the instructors mention that communication instruction is housed within an interdepartmental unit with aims that move beyond communication instruction to focus on other dimensions of engineering, specifically, the engineer in society or engineering education more broadly. This type of transdisciplinary approach to instruction however, in which communication is instructed alongside other professional skills, is described by multiple instructors. In fact, when selecting material for inclusion in the table, it was difficult to determine whether to include these types of engineering professionalism or engineering and society courses: these were common in all plans of study (required curriculum) as found on the university websites, but highlighted by only some of the instructors interviewed. This grouping of communication alongside non-technical skills could be interpreted as either a positive or negative. On the one hand, the development of these types of programs and courses implicitly acknowledges the value of non-technical skills that will support student success throughout their degree and into their careers. On the other hand, it may suggest a conflation of these "soft skills" into one course or suite of courses, that can be more easily siloed off from the technical core.

Two instructors describe either degree granting programs with a significant communication component or a degree-level certificate in communication. These types of initiatives may signal a faculty-wide willingness to expand engineering education beyond the purely technical, and to consider engineering as a professional field that intersects with other areas of study, in the humanities, social sciences or education.

The course-specific activities described are, with the exception of one course, all active in nature, and to varying degrees incorporate collaboration, peer review and iteration. No course focuses on written communication alone, instead incorporating instruction and delivery in oral communication and sometimes visual communication as well. These types of models contrast historical approaches to communication instruction, which privileged written documents above other common modes of engineering communication.
Six of the instructors explicitly describe communication instruction through more than one channel: as a mix of standalone courses, technical courses with significant communication content, or assignment specific instruction. Based on the website review it is clear that this type of hybrid approach is typical at all eight schools. A range of delivery styles suggests a dynamic approach to curriculum planning, in which the most viable method to cover communication skills may change according to the needs of a given department and the availability of instructional time and resources.

\section{CONCLUSION}

The somewhat piecemeal nature of communication instruction presented a challenge when assembling data from the website review after completing the interview stage of this project. As noted above, panelists were encouraged to focus on their experience as engineering communication instructors, by describing the courses and activities in which they are actively engaged. While able to provide an in-depth description of their departmental context, not all panelists provided a complete picture of how communication instruction is organized at the faculty level, and how and where requirements beyond their departmental offerings are planned and delivered. Academic websites provide a similarly incomplete picture, in which the organization and content of service courses could only be uncovered through a maze of websites from multiple academic units. A lack of high-level clarity speaks to the value of exercises like this one. It is also a product of the range of different approaches to communication instruction adopted by faculties with varying investment in non-technical subjects. In some instances, engineering communication educators are supported in institutions that clearly place considerable focus on developing strong communicators, evidenced by centralized units, specialized electives, or the institutional values reflected in a general education or liberal arts degree. In others, engineering communication educators must work to advocate for their subject by negotiating opportunities to provide effective instruction via a potpourri of technical courses and non-technical requirements.

The exercise also revealed the siloed nature of communication instruction across institutions. Multiple respondents described their instructional models or administrative structures as unique, despite their similarities with other initiatives described by other participants. This trend speaks to an understandable investment in the activities of one's own institution, but may also belie a lack of awareness of the activities of other institutions. CEEA provides an exciting opportunity to begin a conversation that can help support continued innovation and improvement within engineering communication instruction in Canada. 


\section{References}

[1] Engineers Canada, "Graduate Attributes," Engineers Canada. [Online.] Available: https://engineerscanada.ca/sites/default/files/GraduateAttributes.pdf. [Accessed Jan 14, 2019.]

[2] ABET, "Criteria for Accrediting Engineering Programs, 2019-2020," ABET. [Online.] Available: https://www.abet.org/accreditation/accreditationcriteria/criteria-for-accrediting-engineering-programs2019-2020/\#GC3. [Accessed Jan 14, 2019.]

[3] H. J. Passow, "Which ABET Competencies Do Engineering Graduates Find Most Important in Their Work?" Journal of Engineering Education, vol. 101, no. 1, Jan 2012.

[4] H. Jang, "Identifying $21^{\text {s }}$ Century STEM Competencies Using Workplace Data," Journal of Science Education and Technology, vol. 25, no. 2, April 2016.

[5] S. Hawse, "Transitioning to Professional Work: A View from the Field," in Success in Higher Education, L. Wood and Y. Bryer, Eds. Singapore: Singapore, 2017.

[6] M. Eraut, "Transfer of Knowledge between Education and Workplace Settings" in Knowledge Values and Educational Policy: a Critical Perspective, H. Daniels, H. Lauder \& J. Porter, Eds. Abingdon, Oxon: Routledge, 2009.

[7] P. Tynjala, "Perspectives into Learning at the Workplace," Educational Research Review, vol 3, no. 2, 2008.

[8] P. Tynjala, V. Slotte, J. Nieminen, K. Lonka, E. Olkinuora, "From University to Working Life: Graduates' Workplace Skills in Practice" in Higher Education and Working LifeCollaboration, Confrontation and Challenges, Elsevier Ltd., 2006.
[9] R. Korte, S. Sheppard, J. William, "A Qualitative Study of the Early Work Experiences of Recent Graduates in Engineering," Proceedings of 2008 American Society for Engineering Education Conference.

[10] J. Trevelyan, "Engineering Education Requires a Better Model of Engineering Practice" Proceedings of the Research in Engineering Education Symposium 2009, Palm Cove, QLD.

[11] J.W. Pellegrino, M.L. Hilton, M.L. Education for life and work: Developing transferable Knowledge and Skills in the 21st Century. National Research Council. National Academic Press: Washington DC, 2012.

[13] S. M. Katz, "The Entry-Level Engineer: Problems in Transition from Student to Professional," Journal of Engineering Education, vol. 82, no. 3, July 1993.

[14] J.D. Lang, S. Cruse, F.D. McVey, J.H. McMasters, "Industry Expectations of New Engineers: a Survey to Assist Curriculum Designers," Journal of Engineering Education, vol. 88 , no. $1,1999$.

[15] J. D. Bakos, "A Departmental Policy for Developing Communication Skills of Undergraduate Engineers," Engineering Education, vol. 77, no. 2, 1986.

[16] D. R. Woods, I. A. Feuerstein, "On Teaching Technical Communication," Engineering Education, vol. 70, no. 7, 1980.

[17] L. Reave, "Technical Communication Instruction in Engineering Schools: a Survey of Top-Ranked U.S. and Canadian Programs," Journal of Business and Technical Communication, vol. 18, no. 4, 2004. 